J-DEPACE, Volume 2, Nomor 2, Desember 2019, Hal 127-135

Tersedia online di :http://jurnal.lpmiunvic.ac.id/index.php/jpkm

\title{
TEKNIK BUDIDAYA LEBAH Trigona sp. DI DALAM BAMBU
}

\author{
Cornelia. M.A. Wattimena, M. Loiwatu, L. Pelupessy \\ Program Studi Kehutanan Universitas Pattimura \\ J1. Ir. M. Putuhena, Kampus Poka-Ambon \\ Email: wattimenacma@gmail.com
}

\begin{abstract}
ABSTRAK
Salah satu hasil hutan non kayu adalah serangga berguna lebah madu diantaranya Lebah Trigona sp. Trigona sp. dikategorikan sebagai kelompok serangga sosial yang memiliki banyak manfaat, dan berkhasiat untuk kesehatan. Sarang lebah Trigona sp di Desa Suli sangat banyak ditemukan pada lubang-lubang goa, kusen-kusen pintu atau jendela milik masyarakat, sehingga untuk memanen madu atau propolis dari lebah Trigona sp, membutuhkan anggaran yang besar karena kusen pintu atau jendela harus dibongkar. Pengabdian ini dilakukan di desa Suli, berupa penyuluhan tentang beternak lebah tanpa sengat (Trigona $s p$ ) di dalam sarang ruas bamboo, dengan tujuan untuk menambah wawasan dan pengetahuan masyarakat tentang teknik budidaya lebah Trigon $s p$ menggunakan sarang bambu sebagai tempat berkembang biak atau media yang mudah didapat dengan biaya yang murah. Teknik budidaya lebah Trigona $s p$ di dalam bambu dimulai dari pembuatan rumah lebah dari bambu, menggergaji bambu dan membuat cincin, memindahkan lebah Trigona $s p$ ke dalam bambu, kemudian bambu ditutup dengan selotip dan bambu siap diletakkan pada tempat yang sudah ditentukan atau disekitar tempat tinggal. Produk yang dihasilkan masih berupa produk mentah, sebab madu, propolis dan roti lebah masih bercampur. Agar siap dipasarkan, maka ketiganya harus dipisahkan.
\end{abstract}

Kata kunci : Teknik Budidaya, Trigona sp, Bambu

\begin{abstract}
One of the non-wood forest products is a useful insect honey bee including "Trigona sp" bees. Trigona sp. categorized as a social insect group that has many benefits, and nutritious for health. Trigona $s p$ bee nest in Suli Village is very much found in cave holes, door frames or window belonging to the community, so to harvest honey or propolis from Trigona $s p$ bee, requires a large budget because the door frame or window must be dismantled. This service is carried out in the village of Suli, in the form of counseling about raising bees without stings (Trigona sp) in the bamboo nest, with the aim to increase public knowledge about Trigon $s p$ bee keeping techniques using bamboo nests as a breeding ground or easily accessible media at a low cost. Trigona $s p$ bee cultivation techniques in bamboo starts from making bamboo bee houses, sawing bamboo and making rings, moving Trigona sp bees into bamboo, then the bamboo is covered with masking tape and the bamboo is ready to be placed in a designated place or around the residence. The resulting product is still a raw product, because honey, propolis and bee bread are still mixed. To be ready to be marketed, the three must be separated.
\end{abstract}

Keywords: Cultivation Technique, Trigona sp, Bamboo 


\section{PENDAHULUAN}

Provinsi Maluku dengan karakterstik wilayah kepulauan memiliki gugus pulau besar dan kecil serta hutan tropis dengan potensi sumberdaya alam hayati yang cukup tinggi dan sangat besar manfaat bagi umat manusia, baik secara langsung maupun tidak langsung. Sebagai salah satu sumber kekayaan alam, maka hutan menghasilkan berbagai hasil hutan berupa kayu maupun non kayu, (Manuhuwa, 2005). Salah satu hasil hutan non kayu adalah serangga berguna lebah madu diantaranya Lebah “Trigona sp”. Keberlangsungan hidup lebah Trigona $s p$ sangat ditunjang oleh faktor lingkungan. Trigona sp. dikategorikan sebagai kelompok serangga sosial yang memiliki banyak manfaat, dan berkhasiat untuk kesehatan

Bambu (Bambusa sp) dapat digunakan sebagai sarang lebah tanpa sengat (Trigona sp). Bambu Patong, bambu jawa, bambu suanggi dan jenis bambu lainnya dengan ketebalan dinding bambu 9-13 cm sangat baik digunakan sebagai sarang lebah karena lebah dapat berproduksi dengan baik sebab kondisi dalam bambu gelap dan terhindar dari gangguan lingkungan lainnya. Faktor lingkungan yang mempengaruhi kegiatan harian lebah Trigona sp di dalam mencari makan adalah suhu udara, kelembaban udara dan intensitas cahaya. Tanaman pakan lebah Trigona sp berupa tumbuhan yang menghasilkan pangan bagi lebah Trigona. Semua jenis tanaman berbunga (tanaman hutan, tanaman pertanian, tanaman perkebunan, tanaman holtikultura dan tanaman liar) yang megandung unsur nektar sebagai bahan madu, polen dan resin sebagai bahan propolis dapat dimanfaatkan sebagi sumber pakan lebah. Aktivitas lebah Trigona mulai keluar dari sarang bambu pada pukul 05.30 WIT sampai dengan pukul 18.00 WIT. Sebelum melakukan aktivitas, lebah Trigona sp akan berdiri di depan sarang ruas bambu untuk menghangatkan badannya sebelum terbang.

\section{MASALAH}

Sarang lebah Trigona sp di Desa Suli sangat banyak ditemukan pada lubang-lubang goa, kusen-kusen pintu atau jendela milik masyarakat, sehingga untuk memanen madu atau propolis dari lebah Trigona sp, membutuhkan anggaran yang besar karena kusen pintu atau jendela harus dibongkar.

Berdasarkan permasalahan tersebut, maka dilakukan pengabdian kepada masyarakat berupa penyuluhan tentang beternak lebah tanpa sengat (Trigona $s p$ ) di dalam sarang ruas bambu. Kegiatan ini diharapkan dapat menambah wawasan dan pengetahuan masyarakat 
tentang teknik budidaya lebah Trigon $s p$ menggunakan sarang bambu sebagai tempat berkembang biak atau media yang mudah didapat dengan biaya yang murah.

\section{METODE}

Metode yang digunakan pada kegiatan ini adalah memberikan pengetahuan kepada masyarakat berupa penyuluhan tentang bagaimana masyarakat desa Suli dapat mengetahui teknik budidaya lebah Trigona sp di dalam bambu.
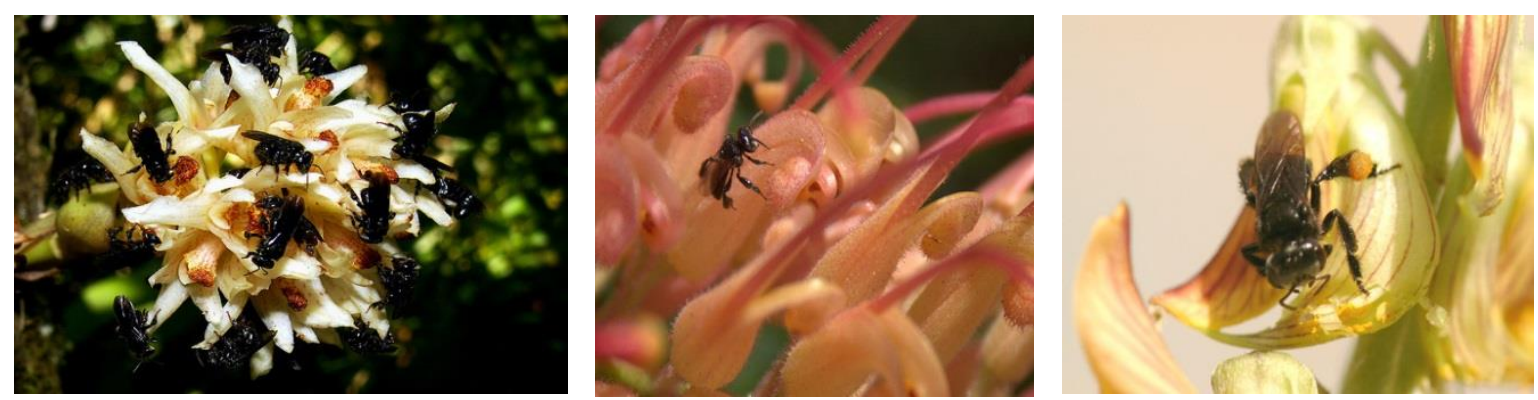

Gambar 1. Bentuk Lebah Trigona sp

\section{HASIL DAN PEMBAHASAN}

Saat ini banyak masyarakat yang memanfaatkan hasil hutan bukan kayu sebagai usaha yang dapat memenuhi kebutuhan hidup. Salah satunya adalah budidaya serangga yang tidak bersengat atau lebah Trigona sp. Lebah ini memiliki karakteristik spesifik yaitu madu yang dihasilkan mempunyai rasa asam namun tahan terhadap fermentasi \& bersifat jarang sekali hijrah serta harga produk madunya lebih tinggi dibandingkan dengan madu produk lebah genus Apis.

Lebah Trigona sp (lebah klanceng), bentuk kecil seperti semut hitam dan hidup di bambu-bambu, lubang kayu, tanah, orang Ambon biasanya menyebut dengan nama "mai-mai Toher”. Lebah Trigona sp adalah serangga sosial yang termasuk dalam ordo Hymenoptera.

\subsubsection{Teknik Budidaya Lebah Trigona sp di Dalam Bambu}

1. Pembuatan Rumah Lebah dari Bambu

Siapkan bambu, dengan ketebalan $9-13 \mathrm{~cm}$, yang terlebih dahulu direndan dalam air mengalir selama 1 (satu) minggu untuk mengurangi selulosa yang ada pada bambu, karena selulosa adalah sumber makanan rayap. 


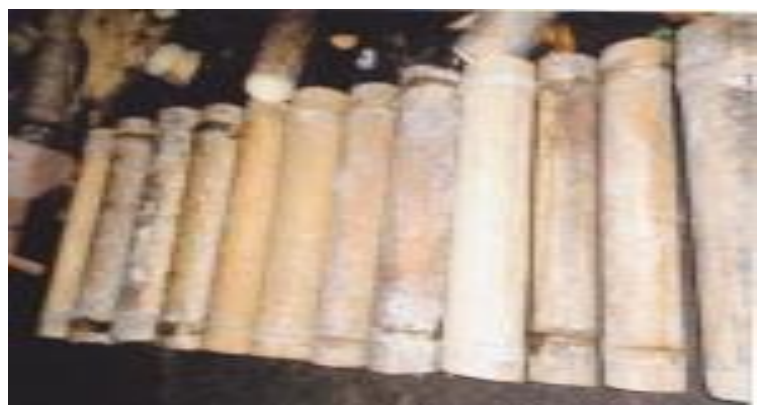

Gambar 2. Rumah Lebah Trigona sp

2. Bambu Digergaji dan di Buat Cincin

Setelah bambu direndam selama 1 (satu) minggu, diangkat dan dikering anginkan. Setelah itu bambu digergaji dan dibuat cincin/lubang pada salah satu sisi bambu sebagai tempat masuk dan keluar lebah Trigona $s p$ pada cincin tersebut diolesi dengan propolis sehingga mudah dikenali oleh lebah Trigona sp pada saat keluar dan masuk.
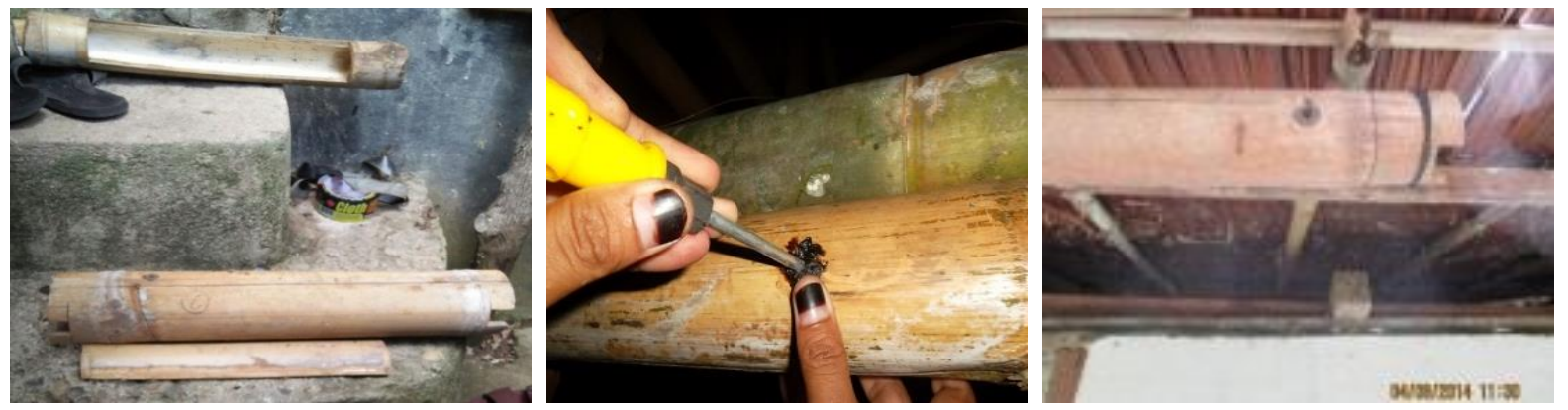

Gambar 3. Bambu Digergaji dan di Buat Cincin

\section{Pemindahan Lebah Trigona sp ke dalam Bambu}

Pindahkan lebah ratu kedalam bambu tersebut. Kalau tidak ditemukan ratu pada sarang sebelumnya (goa-goa, lubang-lubang pohon, kusen-kusen pintu atau jendela) masukkan telur tua yang berwarna agak gelap dan telur muda dengan warna yang terang. Kemudian disusun berderet sebagai berikut : telur tua - telur muda - beebread - kantung madu
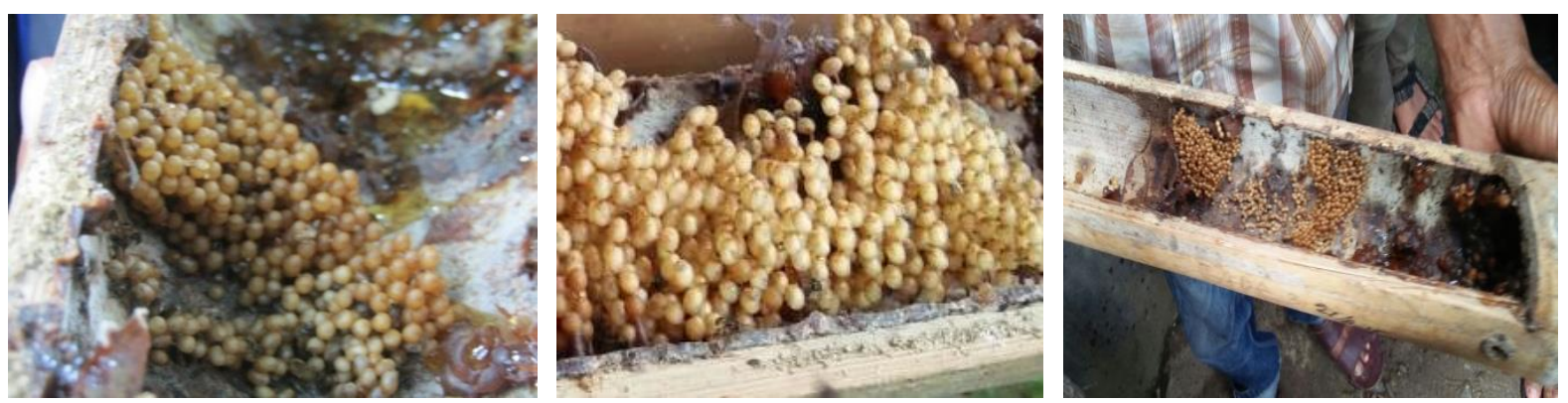

Gambar 4. Susunan Lebah Trigona sp didalam Bambu 
4. Bambu ditutup dengan selotip dan bambu siap diletakkan pada tempat yang sudah ditentukan atau disekitar tempat tinggal.
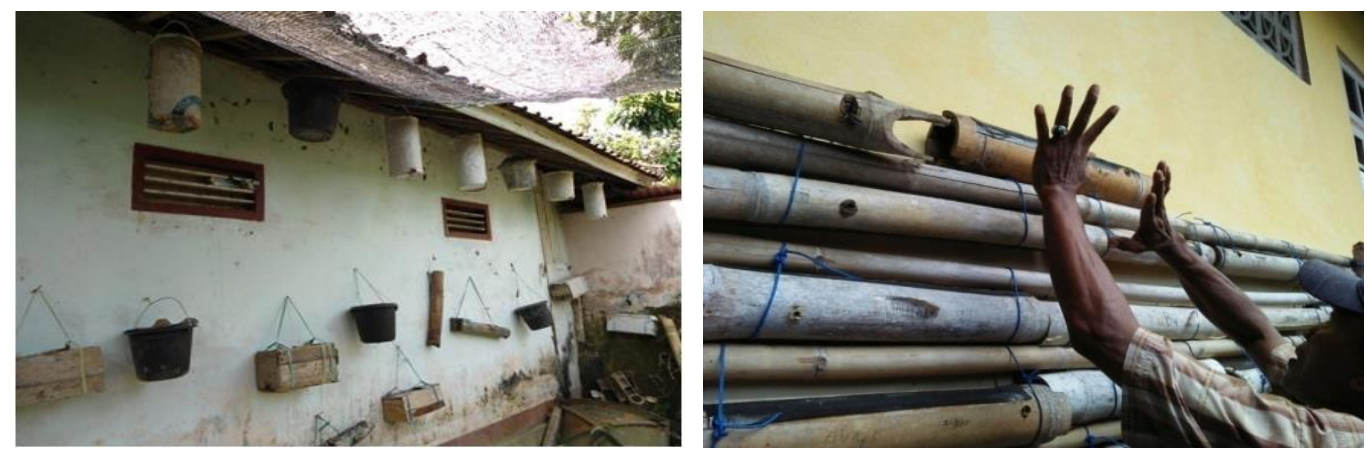

Gambar 5. Peletakan Sarang Bambu

\subsubsection{Cara Panen Lebah Trigona di Dalam Bambu}

Propolis, Madu dan Roti lebah dipanen dengan mengiris setengah bagian isi bambu yang berisi sel-sel cadangan pakan. Bagian itu dipisahkan keluar bambu, lalu "dipecahpecah”. Madu dan roti lebah dikeluarkan dari sel-sel penyimpanan. Sel-sel penyimpanan yang terisi dicetak menjadi lempengan-lempengan membulat lalu diekstraksi untuk mendapatkan propolisnya.

1. Siapkan masker (wearpark) untuk melindungi diri dari kerumunan lebah Trigona sp.

2. Ruas bambu siap dipanen setelah 2-3 bulan

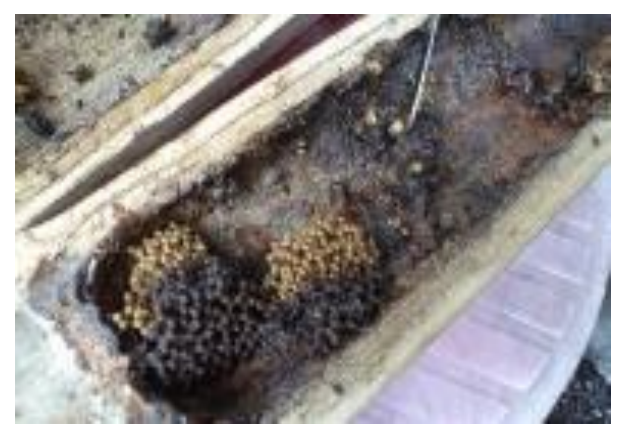

3. Siapkan pisau dan loyang untuk menampung hasil panen. Gunakan pisau tajam untuk memutus rekatan sarang di dinding bambu.

4. Bila sarang banyak, sebagian dicungkil untuk dipindahkan ke sarang baru.

5. Angkat sarang. Bila ukuran cukup besar, bisa dipotong 2 bagian. Sebagian dimasukkan dalam kotak sarang baru.

6. Angkat propolis berisi madu dan roti lebah (bee bread). Juga bulatan seukuran buah kersen berisi madu dan roti lebah ke dalam baskom. Sisakan sebagian di bambu sebagai cadangan makanan bagi lebah Trigona untuk mencegah lebah meninggalkan sarang. 
7. Hasil panen adalah propolis, madu dan bee bread.

8. Bambu yang sudah dimasukkan dipotong. Sarang kembali ditutup dan letakkan di posisi semula. Pastikan posisi sarang lurus dan tak miring untuk mencagah larva mati.

Produk tersebut adalah produk mentah, sebab madu, propolis dan roti lebah masih bercampur. Agar siap dipasarkan, maka ketiganya harus dipisahkan.

\subsubsection{Pengolahan Propolis Untuk Dijual}

Propolis yang berbentuk hitam padat itu tidak menarik dikonsumsi langsung. Kalau dipasarkan harganya sangat rendah. Jadi perlu diolah dengan cara :

1. Siapkan hasil panen madu, propolis dan bee bread.
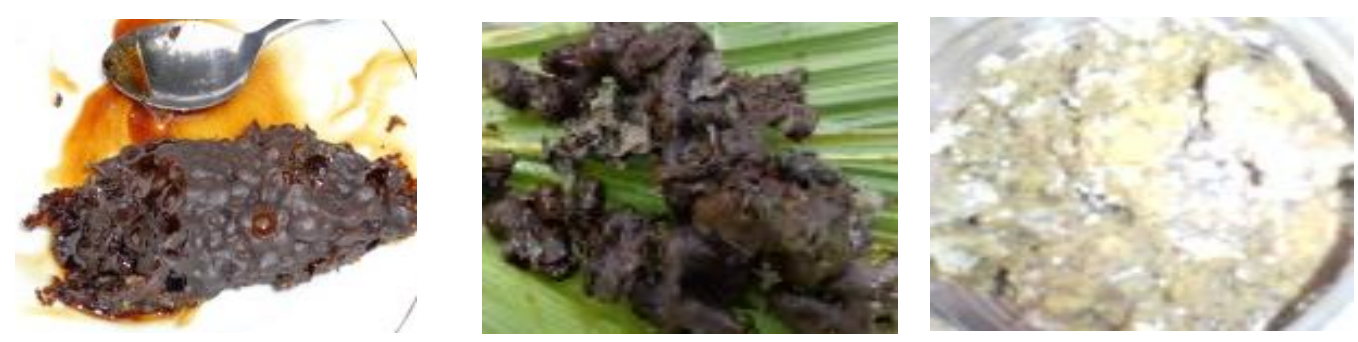

2. Pisahkan madu dengan memasukkan roti lebah dan sarang yang berisi propolis ke dalam kain bersih untuk menyaring kotoran

3. Panaskan dalam air mendidih. Sarang akan mencair dan larut dalam air, sedangkan kotoran tertinggal di kain penyaring

4. Masukkan sarang propolis ke dalam cetakan. Setelah dingin, lepaskan dari cetakan dan bungkus dengan plastik.

5. Kini sarang propolis siap dipasarkan dan diekstrak propolisnya.

\subsubsection{Khasiat Propolis}

Menurut Hotnida dkk (2011), propolis termasuk produk alami berupa bahan resin yang dikumpulkan lebah dari pucuk bunga, pucuk daun atau kulit batang tumbuhan seperti pinus, mangga, dan lain-lain. Bahan tersebut oleh lebah madu dicampur dengan polen, lilin, minyak aromatik dan bahan-bahan yang dikeluarkan lewat air liurnya.

\section{Zat- Zat Yang Dikandung Propolis}

Kandungan Propolis terdiri dari :

Resin

Lilin dan asam Lemak

Minyak Esensial
: $45-55 \%$

$: 25-35 \%$

$: 10 \%$ 
Pollen/tepung sari $\quad: 5 \%$

Mineral, Vitamin dan Zat Organik Lain : : 5\%

Propolis mengandung flavonoid, resin, enzim dan polyheral. Manfaat Propolis :

1. Menguatkan selaput sel, mengaktifkan sel

2. Menghidupkan sel mati

3. Mencegah terjadinya pertumbuhan tumor

4. Menstabilkan saraf parasimpatetetik/anti tekanan

5. Anti oksidan dan mencegah ancaman radikal bebas

6. Mengandung vitamin (A,B1,B2,B3,B4,B5,B6,B12, C,D,E)

7. Mengandung mineral dan protein (16 macam asam amino)

Menurut Suranto (2010), manfaat propolis ditinjau dari segi medis :

1). Sebagai anti jamur, antivirus dan antibakteri

2). Anti Oksidan

3). Sebagai Stimulator Sistem Imun (Imuno Stimulator)

4). Atherosklerosis (Pengapuran darah, jantung coroner dan strike))

5). Anti Tumor

6). Sebagai Anti Prostaglandin (Hormon, Radang Sendi dan Asam Urat)

7). Membantu Proses Regenerasi Sel Hati

8). Diabetes Melitus (kencing manis)

9). Gangguan Saluran Pencernaan (Maag, Diare dan Typus)

10). Gangguan Saluran Pernapasan

11). Penyakit Jantung dan Pembuluh Darah

12). Perawatan Luka

13). Anti Stress

Propolis merupakan produk terbaik karena :

1. Speed Effect (Reaksi Cepat)

2. No Range (Tidak Ada Batasan Umur dan Kelamin)

3. Multiguna (Obat Dalam Tubuh Dan luar Tubuh)

4. Health Food (Makanan Kesehatan Untuk yang Sehat maupun yang Sakit)

5. Tidak Ada Efek Samping 


\section{Mekanisme Kerja Propolis}

Membantu proses pemudaan kembali sel-sel dan memperkuat sel-sel sehat, membunuh sel sel kanker serta anti infeksi fatogen (bakteri, jamur, virus dll), membuang racun dari dalam tubuh.

\subsubsection{Sumber Pakan Lebah Madu}

Sumber pakan lebah madu baik itu jenis Apis maupun lebah Trigona sp adalah :

1. Tanaman buah-buahan,

2. Tanaman sayur-sayuran,

3. Tanaman hias,

4. Tanaman pangan dan perkebunan

5. Tanaman kehutanan.

Bunga dari tanaman-tanaman tersebut mengandung sari tanaman (Nektar) dan tepung sari Pollen) sebagai makanan lebah Trigona sp.

\section{SIMPULAN}

Teknik budidaya lebah Trigona sp di dalam bambu dimulai dari pembuatan rumah lebah dari bambu, menggergaji bambu dan membuat cincin, memindahkan lebah Trigona sp ke dalam bambu, kemudian bambu ditutup dengan selotip dan bambu siap diletakkan pada tempat yang sudah ditentukan atau disekitar tempat tinggal.

Lebah Trigona di dalam bambu yang telah dipanen masih dalam bentuk produk mentah, sebab madu, propolis dan roti lebah masih bercampur. Agar siap dipasarkan, maka ketiganya harus dipisahkan.

Trigona sp, saat ini menjadi peluang usaha untuk dikembangkan karena banyak diminati oleh para investor. Lebah Trigona sp. lebih banyak menghasilkan bee propolis yang memiliki multi efek positif bagi sel daripada : madu, royal jelly, bee propolis, bee wax, bee bread dan bee venom. 


\section{DAFTAR PUSTAKA}

Adji Suranto, 2010. Dasyatnya Propolis Untuk Menggempur Penyakit. PT. Agro Media Pustaka. ISBN 979-006-301-1.

Guntoro, Y. P. 2013. Aktivitas dan Produktivitas Lebah Trigona leaviceps di Kebun Polikultur dan Monokultur Pala (Myristica fragrans)

Hotnida C. H. Siregar, Asnath M. Fuah dan Yoke Octovianty. 2011. Propolis, Madu dan Multikhasiat. Penebar Swadaya. ISBN 978-979-002-472-4

Mahani, A. Karim dan Nunung Nurjanah. 2011. Keajaiban Propolis Trigona. Pustaka Bunda.

Manuhuwa, E. 2005. Assesmen Potensi Bambu dan Pemberdayaannya di Pulau Seram. Disampaikan pada Workshop Bambu Kerjasama UNIDO dan Pemda Maluku.

Sihombing. 2015. Ilmu Ternak Lebah. Gadjah Mada University Press. Yogyakarta 